\title{
Assessment-oriented formative test
}

\section{Siti Mina Tamah* and Johannes V.D. Wirjawan}

\author{
Widya Mandala Catholic University, \\ Dinoyo 42-44, Surabaya 60265, Indonesia \\ Email:mina@ukwms.ac.id \\ Email: wirjawan@ukwms.ac.id \\ *Corresponding author
}

\begin{abstract}
Administering formative tests during instructional process in one academic year is prevalently individual-oriented - expecting students to do the quizzes individually - similar to the one when a summative test is carried out. The challenge appears when teachers have implemented group work, but they still implement non-group work oriented formative tests. The underlying argument is that it is essential for formative test administration to come closer to the paradigm implemented regularly. The class session for regular basis should be reflected in the test class session. This paper aims at introducing the insights of executing authentic assessment in the formative test administration while keeping student engagement. They include: 1) the change from individual assessment into group assessment; 2) the change from individual assessment into representative assessment; 3) the change from individual assessment into representative assessment with structured discussion. Furthermore, the encouraging voice of a group of language teachers following group assessment workshop will be revealed.
\end{abstract}

Keywords: formative test; group work; representativeness; structured discussion; authentic assessment; innovation.

Reference to this paper should be made as follows: Tamah, S.M. and Wirjawan, J.V.D. (2019) 'Assessment-oriented formative test', Int. J. Innovation and Learning, Vol. 26, No. 1, pp.66-81. DOI: 10.1504/IIL.2019.10021091

Biographical notes: Siti Mina Tamah has been a full-timer at the English Department of Widya Mandala Catholic University, Surabaya, Indonesia since 1989. She has great interest in language teaching methods. She has also been involved in teaching at the English Education Department Graduate School. Her current research topics are related to cooperative learning and assessment.

Johannes V.D. Wirjawan earned his $\mathrm{PhD}$ in Physics in 1997 from the Texas A\&M University. He joined the teaching staff members of Physics Education Study Program of Widya Mandala Catholic University Surabaya in 1985. His engagement in education research started in 2004, especially in physics education research. 


\section{Introduction}

Group work or pairing/grouping students to carry out an academic classroom task has been a prevalent phenomenon in classroom instruction. It is evident that small groups of students working on a task are applied as the everyday practice in language classes (McDonough and Shaw, 2003 in Tamah, 2011; Tamah and Prijambodo, 2014; Xethakis, 2016). In Indonesia, this student-centred instruction has been encouraged to be implemented since Curriculum 2006 and Curriculum 2013 were issued. Tamah (2013a) has even argued for the use of group work on the very first meeting of a new academic year when introducing classroom rules.

In one common circumstance, a test is essential for a research as it can function as an indicator of abilities or an attribute remarkable in research on language, language acquisition, and/or language teaching. In the other circumstance, a test is vital for education as it can function as sources of information for making decisions within the context of educational programs (Roshan, 2016).

A classic literature on test concerns test administration. When talking about test administration, Cohen (1980) in a section in his book, puts forward the issues on whether a test will be administered in an average-sized class or in a large hall, and whether it is an open-book or closed book format. Hughes (1989) provides a set of 20 points to take into consideration when administering a test. It is commenced with the points in preparation step covering issues like materials and equipment, examiners, invigilators, candidates and rooms, and the steps in test administration itself which states among others that test takers should be required to arrive well before the test starts, that the identity of the test takers should be checked, and that invigilators should ensure test takers stop work straightaway when they are told to do so.

When test administration is elaborated, the concern is primarily on the test taking processes or the physical environment (Bachman, 1990 in Roshan, 2016). It talks about test delivery or a set of procedures that are usually followed and that are not to be ignored since "mistakes, inconsistencies or abnormalities at any stage in the test administration process can threaten validity" [Fulcher and Davidson, (2007), p.115].

In particular, the discussion on formative test previously presented has been related to procedure-oriented concern. It is also more of a concern on a test of studying outcome (similarly paired with 'assessment of learning'). Meanwhile, assessment researchers will argue for the amendment of formative test focus. It should concern with a test for learning (similarly paired with 'assessment for learning') in order to find more valid ways to measure complex educational goal, namely to find "more educationally friendly variant 'authentic assessment"” (Torrance and Pryor, 1998).

As group work oriented classroom instruction has been a common practice on a day-to-day basis, it is not without its merit to argue that it is indispensable for formative test administration to come closer to the paradigm implemented regularly. The formative test administration is encouragingly shifted to be more of the nowadays assessment in focus. To date no issue has highlighted the administration of formative test which is assessment-oriented.

Two research questions are to be answered:

1 How can teachers shift their role of being an individual-oriented test provider to a formative assessor? 
2 To what extent do teachers perceive assessment-oriented formative test?

This study is an attempt in answer to the call for a more classroom-based, process-oriented approach to come closer to a test for learning - to put the emphasis more on the process in students' doing the test rather than the test result. In brief, the study focuses on three formative assessment insights which are currently introduced to a group of language teachers. It rationalises the development of authentic assessment. The seminar and workshop the teachers attended brings about their voices about the new challenging insights. It is the brief implementation of the three insights.

Before the study presents the main discussion, it will put forward the following underlying theories: formative test, authentic assessments as a conventional test replacement, grouping practice, and group work.

\section{Formative test}

We might be overwhelmed by the following three terms: formative test, formative evaluation, and formative assessment. Which is the correct one? What does 'formative test' in the title of this study refer to?

The term 'formative test' is obviously used in Brown (1996) and Tamah (2015). Some other literature on teaching methods uses the term 'formative evaluation' (Finocchiaro, 1974; Martin, 1992; Robinson, 1991). The term 'formative assessment' is widely spread also (Brown and Abeywickrama, 2010; Hanna and Dettmer, 2004 in Rochmawati, 2015; Harmer, 2007, 2012; Plakans and Gebril, 2015; Warsono and Hariyanto, 2012). A formative test is even evaluated as indicated in the phrase 'evaluating a test' in Tuckman (1975) who talks about test appropriateness, test reliability, validity, interpretability and usability of test results.

Some literature on testing regards test as a part of assessment (Brown and Abeywickrama, 2010; Geyser, 2006; Marzano et al., 2013; Orr, 1999). On the contrary, some argue that testing is only a part of evaluation (Finocchiaro, 1974; Robinson, 1991). These terms appearing in testing literature are revealed to make us aware of various terminologies that might overlap [although Brown and Abeywickrama, (2010) obviously distinguish five terms signifying the interrelationships among: teaching, assessment, measurement, tests, and evaluation - revealing that a test is not part of evaluation). In this study, formative test refers to a way to improve learning and to assess students with regard to administering a test which is bound for the shift from individual-test to group assessment which highlights representativeness with structured discussion (this particular new insight is elaborated later in a separate sub-topic).

\section{Authentic assessments as a conventional test replacement}

Literature on assessment and/or testing (Brown, 2004; Brown and Abeywickrama, 2010; Cohen, 1980; Huda and Freed, 2000; Hughes, 1989) primarily focuses on the 'what and why' to assess or test. It has highlighted issues on testing-centred methods covering test construction, time to test (during or after instruction), washback or effect of testing, test scoring, and test item development and analysis. Typical concern includes, among other, whether the test ought to contain multiple choice type, matching type, or both types, and 
whether the test should be of a teacher made test, or standardised, or published one. This conventional testing is sufficient if the aim is merely to modify performance (Wiggins, 1990). Moreover, this traditional assessment highlighting objective close-ended test items is less intrinsically motivating (Shepard, 2000 cited in Alkharusi, 2008).

The issue on assessment is in fact triggered by the teaching paradigm shift which has introduced the change from teacher-centredness to learner-centredness, or the shift from teaching to learning. This shift from teacher-centredness to learner-centredness has been recommended by prominent educators or theorists since the mid-1980s (Huda and Freed, 2000).

Lake (2003, pp.84-85) points out the shifts 'from pedagogy to androgogy'; 'from passive students to active learners'; 'from teachers to LC (learning centred) educators'; 'from classroom to learning environment'. Meanwhile Radloff and de la Harpe (2001, p.138) put forward the shift from discipline content to the 'skill and will' of learning.

Conventional test has been abandoned as there is shift from 'teacher-led to student-led instruction' (Tamah, 2004), from 'individual oriented test' to 'group oriented assessment' (Tamah, 2014, 2017; Tamah and Prijambodo, 2015), from rote learning to student-centred approach (Wanchid, 2015). Furthermore, Tamah (2013b) asserts alteration from 'old fashioned' teaching mode which is whole-class teacher directed to 'modern' instructional mode which is cooperative learning oriented.

As a replacement of conventional tests, authentic assessment is argued as an assessment for learning. This assessment for learning is in favour of the argument for process-oriented instructional measurement. Rooted from student-centred learning, this assessment is, as pointed out by Jacobs and Renandya (2016), essential to monitor students' own and their peers' learning. Similar terms used to mean the same insight are alternative assessment (Brown and Abeywickrama, 2010; Jacobs and Renandya, 2016; Warsono and Hariyanto, 2012); or holistic assessment (Jacobs and Renandya, 2016) emphasising more on students' performance not on students' studying result. It functions as 'the real mirror' [Warsono and Hariyanto, (2012), p.268] of students' learning condition.

Authentic assessment which is learner-centred supports quality education. Nine rationales are highlighted (Huda and Freed, 2000). First, it promotes high expectation. Authentic assessment is in the form of challenging tasks which are let known even before instruction begins; therefore, students know and understand what is expected from them. Second, it respects diverse talents and learning styles. Third, it increases early years of study. Fourth, it stimulates coherence in learning. Fifth, it synthesises experiences, fosters ongoing practice of learned skills and integrates education and experience. Sixth, it engages students in learning and promotes adequate time on task. Seventh, it provides prompt feedback due to the supporting idea that learners cannot learn without feedback. Eighth, it fosters collaboration. Eventually, it depends on increased student-faculty contact.

With regards to the sixth and eight rationales pointed out by Huda and Freed (2000) mentioned in the previous paragraph, the writers contend it is essential for authentic assessment to include students' engagement and collaboration. This indicates that even when doing the test, the process of learning and collaborating should take place revealing further the encouragement for the diminishing of individual oriented formative test or a conventional formative test. To promote positive interdependence as well as individual accountability among group members, representativeness idea in testing 
should replace individual oriented testing. The additional structured discussion incorporated in the assessment is intended to open students' mind that learning is helping one another: "When I tell or explain what I know, I learn something. My understanding is reinforced. When I ask for help, I will understand more." It is even indicative that the cooperation should exist appropriately during the test - group learning still occurs in formative testing.

Table 1 is presented as a summary of the above descriptive discussion to reveal the difference between conventional test and authentic assessment which is argued.

Table 1 Conventional test vs. authentic assessment

\begin{tabular}{llr}
\hline & \multicolumn{1}{c}{ Conventional test } & Authentic assessment \\
\hline 1 & It focuses on what and why to test. & It focuses on how to assess. \\
2 & It is summative test oriented. & It is formative test oriented. \\
3 & It is teacher-centred. & It is student-centred. \\
4 & It is teacher-centred. & It is educator-centred. \\
5 & It is pedagogy-centred. & It is andragogy-centred. \\
6 & It designates passive students. & It designates active students. \\
7 & It focuses on discipline content. & It focuses on the skill and will of learning \\
8 & It is a test of learning (a test of studying outcome) & It is assessment for learning. \\
9 & It is individual oriented. & It is group oriented. \\
10 & It is individual oriented. & It is representative-oriented. \\
\hline
\end{tabular}

\section{Grouping practice}

Originally the practice of student grouping was introduced by an educational reformer W.T. Harris in 1867 (Kulik and Kulik, 1982 in Marzano et al., 2001). Marzano et al. (2001) further point out three strategies covering: homogeneous, heterogeneous, and cooperative grouping strategies. Including in the last strategy is cooperative learning. They put it, "Fundamentally, cooperative learning falls within the more general view of 'grouping' strategies" [Marzano et al., (2001), p.85].

In Indonesia the grouping practice has initially been mandated by the official authority (prescribed in the 2006 and 2013 Curriculums). This top-down mandate has highlighted the implementation of the constructivist paradigm to provide more chance to the students to be active learners to engage themselves more in knowledge construction abandoning the reliance on knowledge transmission from teachers to students. Grouping strategies have replaced teacher-fronted instruction.

When group work is structured more systematically, its implementation has been advantageous for various merits, among others, improving academic achievement (Slavin, 1980; Stevens and Slavin, 1995; Tran, 2014), and increasing understanding of a text discussed in group (Khan and Ahmad, 2014; Sari and Tamah, 2015; Tamah, 2011). Tamah (2011) further finds that the involvement reveals far more complex interaction pattern than the common initiation - response - feedback (IRF) classroom teaching instruction. As argued by John-Steiner, Panofsky and Smith (1994 in Tamah, 2011), social environment created during group work is a potential one for language acquisition. 
One of the numerous reasons for the implementation of group work is, as argued by Tamah (2017), the willingness of classroom teachers to change. Tamah further puts it, "Guru tersebut berbesar hati rela meninggalkan panggung sentris guru yang sebelumnya menjadi kebanggaannya yang tak tergantikan" (p.12) [translation: The teacher is heartily willing to leave his/her private stage which had previously become his/her irreplaceable pride].

\section{Group work: common vs. structured}

Since the heyday of cooperative learning, group work has been discussed to differentiate between the common group work and the cooperative learning-oriented group work. The former refers to group work where student-centredness is the emphasis as the contrast with teacher-whole class instruction. The teacher leaves his or her classroom stage and surrenders the stage to the students. The classroom has been filled with mushrooms in the form of small groups of students carrying out the instructional tasks assigned by their teachers (Tamah, 2017). Students work in group with the teacher as a facilitator replacing the role of 'Mr. know-all'.

As seen in Table 2, there are at least eight issues differentiating between the common group work and the cooperative learning-oriented group work.

Table 2 Traditional vs. cooperative group work

\begin{tabular}{|c|c|c|}
\hline & Traditional group work & Cooperative group work \\
\hline 1 & $\begin{array}{l}\text { A bit wild; some students dominate, or } \\
\text { the reverse occurs: some are free-riders. }\end{array}$ & $\begin{array}{l}\text { Controlled; positive interdependence is } \\
\text { enforced and promotive interaction takes place. }\end{array}$ \\
\hline 2 & $\begin{array}{l}\text { Individual accountability is ignored; } \\
\text { certain students' hitch hiking is noticed. }\end{array}$ & Individual accountability is recognised. \\
\hline 3 & $\begin{array}{l}\text { Interaction seems to be destructive as } \\
\text { verbal attack occasionally occurs. }\end{array}$ & $\begin{array}{l}\text { Interaction is effective as social and } \\
\text { interpersonal skills are present due to the } \\
\text { intention to support one another. }\end{array}$ \\
\hline 4 & $\begin{array}{l}\text { Main focus is on the completion } \\
\text { of group work (final product). }\end{array}$ & $\begin{array}{l}\text { Main focus is not only on the completion of } \\
\text { group work (final product) but also on } \\
\text { interpersonal relation. }\end{array}$ \\
\hline 5 & Homogeneous grouping is applied. & Heterogeneous grouping is applied. \\
\hline 6 & $\begin{array}{l}\text { Social skill is assumed present so the } \\
\text { skill is not taught to the students. }\end{array}$ & Social skill is taught intentionally. \\
\hline 7 & $\begin{array}{l}\text { No team building is attempted before } \\
\text { group work is implemented. }\end{array}$ & $\begin{array}{l}\text { Special time is allocated for team building } \\
\text { before group work is implemented. }\end{array}$ \\
\hline 8 & No reflective group learning is provided. & $\begin{array}{l}\text { Reflective group learning is provided for the } \\
\text { group to enhance group performance. }\end{array}$ \\
\hline
\end{tabular}

$$
\begin{array}{ll}
\text { Source: } & \text { Tamah (2017; synthesising Cohen, 1994; Smith, 1996; Nurhadi, } \\
& \text { 2004; Cottell, 2010) }
\end{array}
$$

It is then high time that the first research question was briefly pointed out here: Teachers can shift their role of being an individual-oriented test provider to a formative assessor by orienting to group. The group-oriented test is implemented by choosing representatives implying that not all group members are tested. The discussion is still allowed in formative test; however, the discussion is structured. 


\section{The three insights newly introduced}

Cooperative learning approach or group oriented classroom instruction paradigm has been of keen interest to many researchers. While Astuti and Lammers (2017) are concerned with teachers' low level of CLT teaching methodology, the writers are arguing for the need for serious escort.

Referring to a research report (Tamah and Prijambodo, 2014) and the explicit ideas of representativeness in assessment (Tamah and Prijambodo, 2015; Tamah, 2017), three current debatable insights with regard to assessment-oriented formative test are highlighted in this sub-topic. The first insight embodies the change from individual assessment into group assessment. The second embodies the change from individual assessment into representative assessment, and the third articulates the change from individual assessment into representative assessment with structured discussion.

In practice, the nature of group work is lost in the assessment (Larsen-Freeman and Anderson, 2011; Tamah, 2017; Tamah and Prijambodo, 2015). Group oriented teaching has been a common phenomenon, but individual oriented formative test follows. The change from individual assessment into group assessment is introduced as it is argued that it is essential for formative test to resemble the teaching and learning practice in the regular basis. This particular first insight is then trying to respond to the emerging inappropriateness. When group work has been implemented in regular basis, it is inevitable that the formative test is also group-oriented. The 'soul' of cooperation should be kept when the formative test is administered. There should be no deviation between the regular group work practice and the formative test practice. In regular learning basis, the soul of group work has been maintained. It is thus crucial for teachers to create testing atmosphere where the soul of cooperation is maintained as well.

The change from individual assessment into representativeness-oriented assessment suggests that two roles of quiz takers (test takers) and non-quiz takers (test takers) should appear in each group. The students becoming the quiz takers work individually. Meanwhile the ones becoming the non-quiz takers work together - they are assigned to be ready to assist the quiz takers. Ideally groups of four students are formed - resulting in a pair of quiz takers and a pair of non-quiz takers. The idea of representativeness shall reveal the enforcement of positive interdependence and individual accountability. On the first stage which is $100 \%$ of quiz time, the quiz takers are on their own effort to do their best for the group; at the same time, unlike the quiz takers who work individually, the non-quiz takers are encouraged to work together to help each other so that each is later on his or her own to assist the quiz takers. On the second stage which is $50 \%$ of quiz time, each quiz taker is paired with the non-quiz taker. This is structured in such a way that all is done in pairs not the four of them together. On the third stage which is about $10 \%-15 \%$ of quiz time, the non-quiz takers leave the quiz takers on their own. The quiz takers tidy their work and decide which answers to keep. The positive interdependence is strengthened more especially when the scores of the quiz takers are averaged and apply for each student present in the group.

The argument for the change from individual assessment into representative assessment with structured discussion lies in the insight that meaning is constructed through collaborative activity. Classroom is a community of practice where mutual engagement can take place. Each group member brings a significant contribution. Freedman and Ball (2004 in Murniati, 2008) argue that efficient learning takes place when dialogues are present in contextual circumstances. This idea also resonate social 
interactionists' perspective. New knowledge and understanding comes into existence when it is communicated - constructed and negotiated through talk (Mercer, 1995 in Tamah, 2011) or through interaction (Wenger, 1998 in Murniati, 2008).

In this newly introduced idea, structured discussion is another key element. The pair in discussion stage (as explained in the previous paragraph) should be set for heterogeneous pair (low and high achievers). The existence of discussion in this assessment-oriented formative test will create a non-threatening atmosphere instead of stage fever which is created in an individual oriented test. Structured discussion available creates friendly atmosphere which likely yields increased motivation in students' learning. When one of the writers implemented it in a writing class in 2018, one student wrote in her writing journal,

\begin{abstract}
"Last week...to be honest, this was the weirdest quiz I ever had. Why weird? Because we did our quiz by groups! I don't know if this was effective, but in my opinion, this kind of quiz mechanic had a positive and negative side. On the dark side, some member of our group might be slacking that he/she didn't try his/her best to do the quiz. While on the bright side, I think it's actually good since the quiz was really hard and we get to discuss and learn something from the quiz."
\end{abstract}

The part "While on the bright side, I think it's actually good since...we get to discuss and learn something..." indicates the insight of 'discussion' is advantageous.

\title{
7 Teachers' voice on the three insights
}

The focus of this section was on providing information about high school teachers' perceptions on representativeness-oriented formative test before and after they were engaged in a one-day event covering a seminar, and a workshop.

\subsection{Research instrument}

As the instrument to collect the perceptions on the new insights, a questionnaire involving both open and closed items was formulated in Indonesian. The writer made use of a self-developed questionnaire in which six items were formulated to obtain the information about teachers' perspectives with regard to the three insights.

The formulated items appeared in the questionnaire administered before and after the insights were introduced. Statements to probe the teachers' perception on the new insights introduced were formulated. The responses were collected on a four-point Likert scale: 1 for 'strongly disagree', 2 'disagree', 3 'agree', and 4 'strongly agree'. Open ended questions - under the entry of 'comment' - were also used to get more information about why a certain answer was chosen. Implied is that two sets of questionnaires were used. The pre-seminar and workshop questionnaire included items that initially asked teachers to indicate their identity. It essentially included items for them to indicate their perceptions on representativeness-oriented assessment with structured discussion. The post-event questionnaire - similar in nature - was administered to see the teachers' perception after they joined the seminar and workshop.

Those six items were in fact inserted in a set of questionnaires which became the instrument of a larger research project related to two big issues: the implementation and 
the assessment of very structured group work (Tamah and Wirjawan, in progress). Therefore, the description of the try-out was taken from the in-progress research report.

\subsection{Research instrument try-out}

For the instrument try-out conducted at a high school which was not included in the actual research, a test and retest method was employed. Thirty-three paired questionnaires were available for validity and reliability analysis. However, the number of $\mathrm{N}$ for each item was also varied because some items were not answered either in the test method questionnaire or the retest method questionnaire. The items related to assessment could eventually be obtained only from 24 paired questionnaires.

Certain items like "The implementation of the newly introduced insights will be the first experience for my students later. NO/YES" was not statistically measured for reliability as expert judgment (involving a senior lecturer at a Teacher Training Faculty) was used. And from the try out it was found that the item was understood well by the teachers in the tryout school.

The questionnaire which was measured using Excel Correl was found to be valid. An $\mathrm{r}$ value obtained $(0.718)$ bigger than the $\mathrm{r}$ table $(0.423$; df 22) indicated the criteria of 'valid' research instrument items. By the help of 'Pearson correlation coefficient calculator' available at http://www.socscistatistics.com/tests/pearson, the reliability of the research instrument items was found to be 0.48 - a moderate coefficient (Ary et al., 2010).

Having been piloted, the questionnaire (in Indonesian) was at last distributed with a bit revision (reordering some items to make it more coherent) to 46 target teachers - the ones who attended a one-day seminar and workshop which was financially supported by the Indonesia Ministry of Research and Technology and Higher Education for the dissemination of the new insights. They were high school language teachers sent by their headmaster to join the free of charge seminar and workshop. They were told that a study was being conducted to investigate the difference in perception before and after the seminar and workshop they joined. They were sincerely requested to participate, and if they wished, their responses would remain anonymous and confidential.

\subsection{Data collection}

The disseminating event took place two times in two different venues. The first event was held in a city in East Java province on May 5, 2018, and the second in another province (West Nusa Tenggara) on May 19, 2018 - two weeks after the first event (25 teachers in the first venue and 21 teachers in the second venue participated).

In the 40-minute seminar, the participants were provided with the theoretical information about:

1 cooperative learning paradigm as a review

2 the nuts and bolts of group work

3 the new insights on assessment-oriented formative test previously elaborated.

In the 55-minute workshop of the assessment issue, they experienced a model of assessment-oriented formative test. The teachers were genuinely asked to act as high school students (tenth graders) following a Bahasa Indonesia lesson. One of the authors 
became the teacher. The workshop session represented a regular classroom session when a formative test was scheduled to be administered. The author implemented the test with three stages. The first stage revealed the implementation of having only two students from each group to be quiz takers who worked individually while the other two members from each group became the non-quiz takers who were allowed to work together or to discuss the test problem. The second stage was the discussion time (pairing the quiz takers and non-quiz takers). The third stage was for the quiz takers - after being left alone by the non-quiz takers - to tidy their work. The quiz takers were on their own to decide the answers to score.

\subsection{Data analysis and findings}

Initially, it is wise to reveal the issue of inventiveness of the challenging insights introduced. Asked to respond to "The administration of this representativeness oriented assessment will be the first experience for my students," the majority of the teachers (slightly above $78 \%$ ) pointed out YES before they were introduced to the insights. After the workshop, the percentage for YES increases - reaching 100\%. Before they were introduced to the insights, 10 (slightly below 22\%) teachers misunderstood the illustrated insights written. One of the ten teachers' response "Dalam kelompok ada penyelesaian dari semua tim" [translation: All students in a group discuss together as a team] in the pre questionnaire reveals that this particular teacher misunderstood it. After he/she was engaged in the workshop having a simulation of a model of quiz session, he/she realised that she had never done it - especially with regard to representativeness idea. He/she therefore admitted it would be 'new' thing.

The insights in this assessment-oriented formative test are indeed something inventive as admitted by $100 \%$ teachers (see Table 3 ).

Table 3 The inventiveness perceived by teachers

\begin{tabular}{|c|c|c|c|c|c|}
\hline \multicolumn{3}{|c|}{$\begin{array}{l}\text { "It will be my students' first experience when } \\
\text { the formative assessment is administered" }\end{array}$} & Before $(n=46)$ & \multicolumn{2}{|c|}{$\operatorname{After}(n=46)$} \\
\hline \multicolumn{3}{|l|}{ No } & $10(21.74 \%)$ & \multicolumn{2}{|c|}{$0(0 \%)$} \\
\hline \multicolumn{3}{|l|}{ Yes } & $36(78.26 \%)$ & \multicolumn{2}{|c|}{$46(100 \%)$} \\
\hline \multicolumn{2}{|l|}{ Total } & \multicolumn{2}{|r|}{$100 \%$} & \multicolumn{2}{|c|}{$100 \%$} \\
\hline \multicolumn{6}{|c|}{ Table 4 The usefulness perceived by teachers } \\
\hline $\begin{array}{l}\text { "Usefulness of the } \\
\text { assessment-oriented } \\
\text { formative test" }\end{array}$ & $\begin{array}{l}\text { Before } \\
(n=46)\end{array}$ & $\begin{array}{c}\text { After } \\
(n=46)\end{array}$ & & $\begin{array}{l}\text { Before } \\
(n=46)\end{array}$ & $\begin{array}{c}\text { After } \\
(n=46)\end{array}$ \\
\hline Strongly disagree & $0(0 \%)$ & $0(0 \%)$ & \multirow{2}{*}{$\begin{array}{l}\text { Not } \\
\text { useful }\end{array}$} & \multirow[t]{2}{*}{$6.52 \%$} & \multirow[t]{2}{*}{$2.17 \%$} \\
\hline Disagree & $3(6.52 \%)$ & $1(2.17 \%)$ & & & \\
\hline Agree & $33(71.73 \%)$ & $19(41.30 \%)$ & \multirow[t]{2}{*}{ Useful } & \multirow[t]{2}{*}{$93.46 \%$} & \multirow[t]{2}{*}{$97.83 \%$} \\
\hline Strongly agree & $10(21.73 \%)$ & $26(56.53 \%)$ & & & \\
\hline Total & $100 \%$ & $100 \%$ & & $100 \%$ & $100 \%$ \\
\hline \multicolumn{3}{|c|}{ Likert-scale oriented insight (1-4) } & & 3.15 & 3.54 \\
\hline
\end{tabular}


With regard to the usefulness of the new insights of formative test which is assessment-oriented, the teachers' perception is presented in Table 4.

With regard to the necessity of the new insights of formative test which is assessment-oriented, it is seen from Table 5 that initially the majority of the teachers (about 89\%) thought that the new insights were necessary. After they experienced the model of the test, $100 \%$ teachers thought they were necessary.

Table 5 The necessity perceived by teachers

\begin{tabular}{lccccc}
\hline $\begin{array}{l}\text { "Necessity of the } \\
\text { assessment-oriented } \\
\text { formative test" }\end{array}$ & $\begin{array}{c}\text { Before } \\
(n=46)\end{array}$ & $\begin{array}{c}\text { After } \\
(n=46)\end{array}$ & $\begin{array}{c}\text { Before } \\
(n=46)\end{array}$ & $\begin{array}{c}\text { After } \\
(n=46)\end{array}$ \\
\hline $\begin{array}{l}\text { Strongly disagree } \\
\text { Disagree }\end{array}$ & $\begin{array}{c}1(2.17 \%) \\
\text { Agree }\end{array}$ & $0(0 \%)$ & $\begin{array}{c}\text { Not } \\
\text { necessary }\end{array}$ & $10.87 \%$ & $0 \%$ \\
Strongly agree & $10(21.74 \%)$ & $22(47.83 \%)$ & & $89.32 \%$ & $100 \%$ \\
Total & $100 \%$ & $100 \%$ & Necessary & $100 \%$ & $100 \%$ \\
Likert-scale oriented insight $(1-4)$ & & 3.09 & 3.49 \\
\hline
\end{tabular}

With regard to the perception on whether the new insights of formative test which is assessment-oriented are likely to make students like the insights, it is found that about $85 \%$ teachers predicted that their students would like the idea. After the teachers experienced the model test, all of them (100\%) perceived that their students would like it (see Table 6).

Table 6 Students' preference perceived by teachers

\begin{tabular}{lccccc}
\hline $\begin{array}{l}\text { "Students will like } \\
\text { the idea" }\end{array}$ & $\begin{array}{c}\text { Before } \\
(n=46)\end{array}$ & $\begin{array}{c}\text { After } \\
(n=46)\end{array}$ & $\begin{array}{c}\text { Before } \\
(n=46)\end{array}$ & $\begin{array}{c}\text { After } \\
(n=46)\end{array}$ \\
\hline Strongly disagree & $0(0 \%)$ & $0(0 \%)$ & Dislike & $15.22 \%$ & $0 \%$ \\
Disagree & $7(15.22 \%)$ & $0(0 \%)$ & & & \\
Agree & $32(69.57 \%)$ & $23(50 \%)$ & Like & $84.78 \%$ & $100 \%$ \\
Strongly agree & $7(15.22 \%)$ & $23(50 \%)$ & & & $100 \%$ \\
Total & $100 \%$ & $100 \%$ & & $100 \%$ & 3.5 \\
\hline Likert-scale oriented insight $(1-4)$ & & 3 & \\
\hline
\end{tabular}

To identify the perception on whether the new insights of formative testing will bring about learning on the students, the teachers were asked to respond to an item in the questionnaire stating "Students' learning happens during the test." The teachers' answers are presented below.

The implementation of the insights is considered beneficial as it is believed to promote learning and at the same time it is also believed that the learning process occurs during the test.

The teachers are also asked if the insights are in accordance to the nature of group work or whether the assessment-oriented formative test resonates the appropriate way to assess group work, their perception is revealed below: 
Table $7 \quad$ Students' learning perceived by teachers

\begin{tabular}{lccccc}
\hline $\begin{array}{l}\text { "Students' learning } \\
\text { takes place" }\end{array}$ & $\begin{array}{c}\text { Before } \\
(n=46)\end{array}$ & $\begin{array}{c}\text { After } \\
(n=46)\end{array}$ & $\begin{array}{c}\text { Before } \\
(n=46)\end{array}$ & $\begin{array}{c}\text { After } \\
(n=46)\end{array}$ \\
\hline Strongly disagree & $0(0 \%)$ & $0(0 \%)$ & No & $4.35 \%$ & $0 \%$ \\
Disagree & $2(4.35 \%)$ & $0(0 \%)$ & & & \\
Agree & $35(76.09 \%)$ & $22(47.83 \%)$ & Yes & $95.65 \%$ & $100 \%$ \\
Strongly agree & $9(19.57 \%)$ & $24(52.17 \%)$ & & & \\
Total & $100 \%$ & $100 \%$ & & $100 \%$ & $100 \%$ \\
Likert-scale oriented insight $(1-4)$ & & 3.15 & 3.52 \\
\hline
\end{tabular}

Table 8 New insights pertinence perceived by teachers

\begin{tabular}{|c|c|c|c|c|c|}
\hline $\begin{array}{l}\text { "New Insights } \\
\text { representing the } \\
\text { nature of group work" }\end{array}$ & $\begin{array}{l}\text { Before } \\
(n=46)\end{array}$ & $\begin{array}{c}\text { After } \\
(n=46)\end{array}$ & & $\begin{array}{l}\text { Before } \\
(n=46)\end{array}$ & $\begin{array}{c}\text { After } \\
(n=46)\end{array}$ \\
\hline Strongly disagree & $0(0 \%)$ & $0(0 \%)$ & No & $21.74 \%$ & $2.17 \%$ \\
\hline Disagree & $10(21.74 \%)$ & $1(2.17 \%)$ & & & \\
\hline Agree & $28(60.87 \%)$ & $23(50 \%)$ & Yes & $78.26 \%$ & $97.83 \%$ \\
\hline Strongly agree & $8(17.39 \%)$ & $22(47.83 \%)$ & & & \\
\hline Total & $100 \%$ & $100 \%$ & & $100 \%$ & $100 \%$ \\
\hline \multicolumn{4}{|c|}{ Likert-scale oriented insight $(1-4)$} & 2.96 & 3.46 \\
\hline
\end{tabular}

Table 9 shows that the average mean rating for all items related to the ideas of the new insights: the usefulness, and the necessity of the insights, the student's preference they bring about, the learning and the pertinence they generate.

Table 9 Overall perception on assessment-oriented formative test

\begin{tabular}{lccccc}
\hline & \multicolumn{2}{c}{ Positive percentage } & & \multicolumn{2}{c}{ Mean rating (four-point scale) } \\
\cline { 2 - 3 } \cline { 5 - 6 } & \multicolumn{1}{c}{ Before } & After & & Before & After \\
\hline Usefulness & $93.46 \%$ & $97.83 \%$ & & 3.15 & 3.54 \\
Necessity & $89.12 \%$ & $100 \%$ & & 3.09 & 3.49 \\
Students' preference & $84.78 \%$ & $100 \%$ & & 3 & 3.5 \\
Students' learning & $95.65 \%$ & $100 \%$ & & 3.15 & 3.52 \\
Representation of & $78.27 \%$ & $97.83 \%$ & & 2.96 & 3.46 \\
nature of group work & & & & 3.05 & 3.49 \\
Average & $88.26 \%$ & $99.13 \%$ & & 3.05 & \\
\hline
\end{tabular}

The respondents' answers showing the extent to which they agree with and consider that they eventually like or dislike the idea is indicated in the following findings presented in Table 10.

From the findings indicated in the option of (A) chosen by the teachers, it is obvious that before they experienced the model of assessment-oriented formative test, only about $33 \%$ were in favour of assessment-oriented formative test. After they experienced the model, the percentage increases and reaches slightly below $74 \%$ - quite an increase. 
The findings having been presented above, the answer to the second research question with regard to the perception on the new insights can now be revealed briefly. It is apparent that the new insights are positively perceived highly. Teachers become more positive toward such assessment after experiencing the model of the assessment-oriented formative test. They initially sound out the theory-oriented answers. However, as they experience it themselves through the workshop, they become more convinced of the merits of the new insights. This study substantiates the finding of Tamah and Prijambodo (2014) disclosing the positive university student perception on the implementation of the formative test which is assessment oriented.

Table 10 New insights on testing or conventional testing

\begin{tabular}{llc}
\hline Preference & Before $(n=46)$ & After $(n=46)$ \\
\hline A $\quad \begin{array}{l}\text { New Insights of } \\
\text { assessment-oriented formative test }\end{array}$ & $15(32.61 \%)$ & $34(73.91 \%)$ \\
B $\quad \begin{array}{l}\text { Individual formative test with } \\
\text { average score taken }\end{array}$ & $23(50.00 \%)$ & $10(21.74 \%)$ \\
C $\quad \begin{array}{l}\text { Individual formative test without } \\
\text { average score taken }\end{array}$ & $8(17.39 \%)$ & $2(4.35 \%)$ \\
Total & $100 \%$ & $100 \%$ \\
\hline
\end{tabular}

Comments from the teachers like "jika dihadapkan pada kelas yang tergolong siswa-siswinya sulit diatur, maka guru perlu ekstra perhatian dan ekstra mengawasi agar berjalan sesuai tujuan yang diinginkan," "mungkin persiapan kuis membutuhkan waktu yang lebih lama," "membutuhkan waktu yang lama untuk penerapan di kelas," and "guru menyiapkan materi lebih dari biasanya dan memerlukan waktu dan tenaga yang khusus pula" [translation: having students hard to control, teachers need extra attention to manage the administration so that the test runs well; maybe the preparation needs considering; and more preparation - time and energy - is needed] implicitly shows that the new insights are something new. Furthermore, the implementation of the insights needs careful preparation from the teachers' side in order not to ruin the practicality of formative testing.

\section{Conclusions}

This paper has described the three insights underlying assessment-oriented formative test. It is grounded in group work issue which is cooperative-oriented to bring about the necessary conditions for tying teaching and assessment in classroom instruction. It highlights the insights of gauging and optimising student performance while doing the formative test. The paper has also depicted how the three insights are responded by a group of teachers.

The study will trigger future researchers to the call for a more classroom-based, contextualised approach which can inform instructors and course designers about best practices for enhancing student engagement during a process-oriented test administration. Student engagement in the stage of structured discussion during the formative test administration can be further assessed using, for instance, student self-report and teacher report questionnaires to yield more authentic assessment. 


\section{Acknowledgements}

This study is funded by Directorate of Research and Community Service, Directorate General of Research Enhancement and Development and Ministry of Research, Technology and Higher Education. It is based on the agreement letters 3/E/KPT/2018 and $115 \mathrm{C} / \mathrm{WM} 01.5 / \mathrm{N} / 2018$

\section{References}

Alkharusi, H. (2008) 'Effects of classroom assessment practices on students' achievement goals', Educational Assessment, Vol. 13, No. 4, pp.243-266, DOI: 10.1080/10627190802602509 [online] https://doi.org/10.1080/10627190802602509.

Ary, D., Jacobs, L.C. and Sorensen, C. (2010) Introduction to Research in Education, Cengage Learning, Wadsworth.

Astuti, P. and Lammers, J.C. (2017) 'Making EFL instruction more CLT-oriented trough individual accountability in cooperative learning', TEFLIN Journal, Vol. 28, No. 2, pp.236-258 [online] http://journal.teflin.org/index.php/journal/article/download/463/288 (accessed 1 September 2017).

Brown, D.H. (2004) Language Assessment: Principles and Classroom Practices, Longman, New York.

Brown, H.D. and Abeywickrama, P. (2010) Language Assessment: Principles and Classroom Practices, 2nd ed., Pearson Education, Inc., New York.

Brown, J.D. (1996) Testing in Language Programs, Prentice Hall Regents, New Jersey.

Cohen, A.D. (1980) Testing Language Ability in the Classroom, Newbury House Publishers, Inc., Rowley, MA.

Finnochiaro, M. (1974) English as a Second Language: From Theory to Practice, Regents Publishing Co., New York.

Fulcher, G. and Davidson, F. (2007) Language Testing and Assessment: An Advanced Resource Book, Routledge, New York.

Geyser, J.P. (2006) English to the World: Teaching Methodology Made Easy, August Publishing Sdn. BHD, Kuala Lumpur.

Harmer, J. (2007) The Practice of English Language Teaching, 4th ed., Pearson Education Limited http://bookfi.org/dl/1284440/268fe1 (accessed 2 August 2016).

Harmer, J. (2012) Essential Teacher Knowledge: Core Concepts in English Language Teaching, Pearson Edu. Limited, Harlow, Essex, UK.

Hughes, A. (1989) Testing for Language Teachers, Cambridge University Press, Cambridge.

Jacobs, G.M. and Renandya, W.A. (2016) 'Student-centred learning in ELT', in Renandya, W.A. and Widodo, H.P. (Eds.): English Language Teaching Today: Linking Theory and Practice, pp.13-23, Springer Nature, Switzerland.

Khan, S.A. and Ahmad, R.N. (2014) 'Evaluation of the effectiveness of cooperative learning method versus traditional learning method on the reading comprehension of the students', Journal of Research and Reflections in Education, Vol. 8, No. 1, pp.55-64 [online] http://www.ue.edu.pk/jrre, http://ue.edu.pk/jrre/articles/81006.pdf (accessed 3 March 2016).

Lake, M. (2003) Learner Centered EFL Exams \& Grading: A Classroom Study Effectiveness [online] https://tci-thaijo.org/index.php/JournalEnglishStudies/article/view/21842/18834 (accessed 10 January 2015).

Larsen-Freeman, D. and Anderson, M. (2011) Techniques and Principles in Language Teaching, 3rd ed., Oxford University Press, Oxford.

Martin, I. (1992) An Invitation to Explore ESP, SEAMEO Regional Language Center, Singapore. 
Marzano, R.J., Pickering, D.J. and Pollock, J.E. (2001) Classroom Instruction that Works: Research-based Strategies for Increasing Student Achievement, Association for Supervision and Curriculum Development, Alexandria.

Marzano, R.J., Yanoski, D.C, Hoegh, J.K. and Simms, J.A. (2013) Using Common Core Standards to Enhance Classroom Instruction \& Assessment, Marzano Research Laboratory, Bloomington.

McMillan, J.H. (1996) Educational Research: Fundamentals for the Consumer, Harper Collins Publishers, New York.

Murniati, C.T. (2008) 'A critique of traditional pedagogical methods in the teaching of English language skills', CELT, Vol. 8, No. 1, pp.59-75.

Orr, J.K. (1999) Growing up with English, Office of English Language Program, Washington.

Plakans, L. and Gebril, A. (2015) Assessment Myths, University of Michigan Press, USA.

Radloff, A. and de la Harpe, B. (2001) 'Expanding what and how we assess: going beyond the content', in Kulski, M. and Hermann, A. (Eds.): New Horizons in University Teaching and Learning: Responding to Change, pp.137-147, Center for Educational Advancement, Perth, Western Australia.

Robinson, P. (1991) ESP Today: A Practitioner's Guide, Prentice Hall International, New York.

Rochmawati, D. (2015) 'A holistic model of English lesson-unit assessment for junior high school students', Indonesian Journal of English Language Studies, Vol. 1, No. 1, pp.31-56.

Roshan, N.A. (2016) 'The principles of good test administration', International Journal of Modern Language Teaching and Learning, Vol. 1, No. 4, pp.126-129 [online] http://www.ijmltl.com./ fulltext/paper-18092016095510.pdf (accessed 1 May 2017).

Sari, C.D. and Tamah, S.M. (2015) 'The effect of collaborative strategic reading on grade six students' reading achievement', Indonesian Journal of English Education, Vol. 2, No. 1, pp.17-27 [online] http://www.journal.uinjkt.ac.id/index.php/ijee/article/download/1501/1811 (accessed 16 June 2016).

Slavin, R.E. (1980) 'Effects of student teams and peer tutoring on academic achievement and time on-task', Journal of Experimental Education, Vol. 48, No. 4, pp.253-257.

Stevens, R. and Slavin, R. (1995) 'The cooperative elementary school: effects on students' achievement, attitudes, and social relations', American Educational Research Journal, Vol. 32, No. 2, pp.321-351.

Tamah, S.M. (2004) 'Shifting from teacher-led to student-led instruction in writing class', a paper presented at Linguistic Conference Kolita 2 Unika Atma Jaya, Jakarta.

Tamah, S.M. (2011) Student Interaction in the Implementation of the Jigsaw Technique in Language Teaching, published dissertation, Groningen University, The Netherlands.

Tamah, S.M. (2013a) 'Introducing classroom rules using the jigsaw technique', A Model. English Edu. Journal of Language Teaching and Research, Vol. 11, No. 1, pp.34-41 [online] http://repository.wima.ac.id/4505/ (accessed 24 June 2015).

Tamah, S.M. (2013b) 'Multi-structural class: what and how it is perceived', TEFLIN Journal, Vol. 24, No. 2, pp.201-219 [online] http://journal.teflin.org/index.php/journal/article/ view/164 (accessed 24 June 2015).

Tamah, S.M. (2014) 'Assessment in a cooperative learning class', PASAA Journal, Vol. 47, No. 1, pp.199-214 (accessed 24 June 2015).

Tamah, S.M. (2015) 'Revitalizing formative test: a model of interactive test administration', Asmaradhani, A.I., Rahayu, E.M. and Karim, M.R.A. (Eds.): Seminar Proceeding: The 2nd National Conference on Language and Language Teaching, PGRI Adi Buana, Surabaya, pp.139-145 [online] http://repository.wima.ac.id/id/eprint/4502 (accessed 6 June 2016).

Tamah, S.M. (2017) Pernak-pernik kerja kelompok berbasis pembelajaraan kooperatif. [translation: The nuts and bolts of Cooperative Learning Oriented Group Work], Unika Widya Mandala, Surabaya [online] http://repository.wima.ac.id/12440/ (accessed 24 August 2017). 
Tamah, S.M. and Prijambodo, L. (2014) Metode asesmen berbasis pembelajaran kooperatif. [translation: Assessment Method: Cooperative Learning Oriented] Research Report, unpublished, Widya Mandala Catholic University Surabaya, Surabaya [online] http://repository.wima.ac.id/4496/ (accessed 24 August 2017).

Tamah, S.M. and Prijambodo, L. (2015) Model asesmen pembelajaran kooperatif: Strategi menjawab tantangan. [translation: Models of Cooperative Learning Assessment: Strategies to Respond to Challenges], Revka Petra Media, Surabaya [online] http://repository.wima.ac.id/4138/ (accessed 24 August 2017).

Torrance, H. and Pryor, J. (1998) Investigating Formative Assessment: Teaching, Learning and Assessment in the Classroom, Open University Press, Maidenhead.

Tran, V.D. (2014) 'The effects of cooperative learning on the academic achievement and knowledge retention', International Journal of Higher Education, Vol. 3, No. 2, p.131 [online] http://www.sciedu.ca/ijhe (accessed 3 March 2017).

Tuckman, B.W. (1975) Measuring Educational Outcomes: Fundamentals of Testing, Harcourt Brace Jovanovich, Inc., New York.

Wanchid, R. (2015) 'Different sequences of feedback types: effectiveness, attitudes, and preferences', PASAA, Vol. 50, No. 2, pp.31-64 (accessed 1 July 2017).

Warsono and Hariyanto (2012) Pembelajaran aktif: Teori dan asesmen, PT Remaja Rosdakarya Offset, Bandung.

Wiggins, G. (1990) 'The case for authentic assessment', Practical Assessment, Research \& Evaluation, Vol. 2, No. 2, pp.1-3 [online] http://pareonline.net/getvn.asp?v=2\&n=2 (accessed 15 May 2015).

Xethakis, L. (2016) 'Creating conditions for collaborative learning in the language classroom', in Brooks, G. (Ed.): The 2016 PanSIG Journal, 2016 PanSIG Conference Innovations in Education, pp.351-357, JALT Central Office, Urban Edge Bldg 5F, 1-37-9 Taito, Taito-ku, Tokyo 110-0016, Nago, Okinawa, Japan, ISBN: 978-4-901352-55-0. 